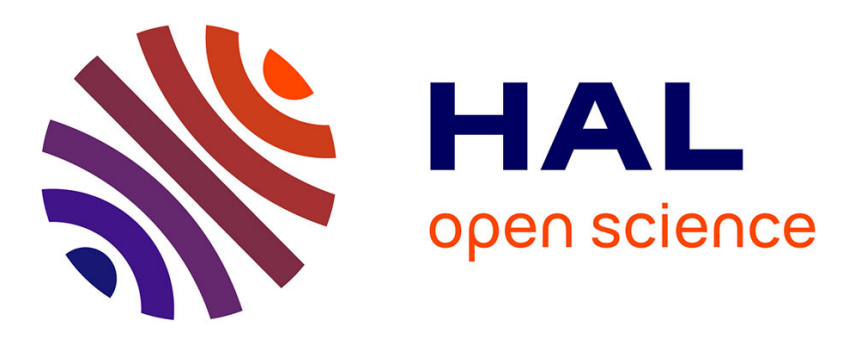

\title{
Determination of Interaction Strength between Corrole and Phenol Derivatives in Aqueous Media Using Atomic Force Microscopy
}

Iwona Szymańska, Eddy Dolusic, Wim Dehaen, Wouter Maes, Takashi Ito, Hanna Jadwiga Radecka

\section{To cite this version:}

Iwona Szymańska, Eddy Dolusic, Wim Dehaen, Wouter Maes, Takashi Ito, et al.. Determination of Interaction Strength between Corrole and Phenol Derivatives in Aqueous Media Using Atomic Force Microscopy. Supramolecular Chemistry, 2009, 21 (07), pp.555-563. 10.1080/10610270802406611. hal-00520012

\section{HAL Id: hal-00520012 \\ https://hal.science/hal-00520012}

Submitted on 22 Sep 2010

HAL is a multi-disciplinary open access archive for the deposit and dissemination of scientific research documents, whether they are published or not. The documents may come from teaching and research institutions in France or abroad, or from public or private research centers.
L'archive ouverte pluridisciplinaire HAL, est destinée au dépôt et à la diffusion de documents scientifiques de niveau recherche, publiés ou non, émanant des établissements d'enseignement et de recherche français ou étrangers, des laboratoires publics ou privés. 


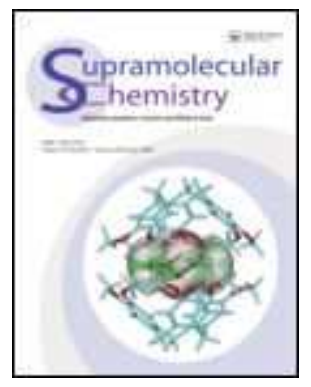

\section{Determination of Interaction Strength between Corrole and Phenol Derivatives in Aqueous Media Using Atomic Force Microscopy}

\begin{tabular}{|c|c|}
\hline Journal: & Supramolecular Chemistry \\
\hline Manuscript ID: & GSCH-2008-0058.R1 \\
\hline Manuscript Type: & Full Paper \\
\hline $\begin{array}{r}\text { Date Submitted by the } \\
\text { Author: }\end{array}$ & $16-J u l-2008$ \\
\hline Complete List of Authors: & $\begin{array}{l}\text { Szymańska, Iwona; Institute of Animal Reproduction and Food } \\
\text { Research of Polish Academy of Sciences } \\
\text { Dolusic, Eddy; University of Leuven, Department of Chemistry } \\
\text { Dehaen, Wim; University of Leuven, Department of Chemistry } \\
\text { Maes, Wouter; University of Leuven, Department of Chemistry } \\
\text { Ito, Takashi; Kansas State Universit, Department of Chemistry } \\
\text { Radecka, Hanna; Polish Academy of Sciences, Department of } \\
\text { Biosensors in Food }\end{array}$ \\
\hline Keywords: & $\begin{array}{l}\text { atomic force microscopy, molecular recognition, corrole, phenol } \\
\text { derivatives, aqueous media }\end{array}$ \\
\hline
\end{tabular}

\section{ScholaroNE" \\ Manuscript Central}




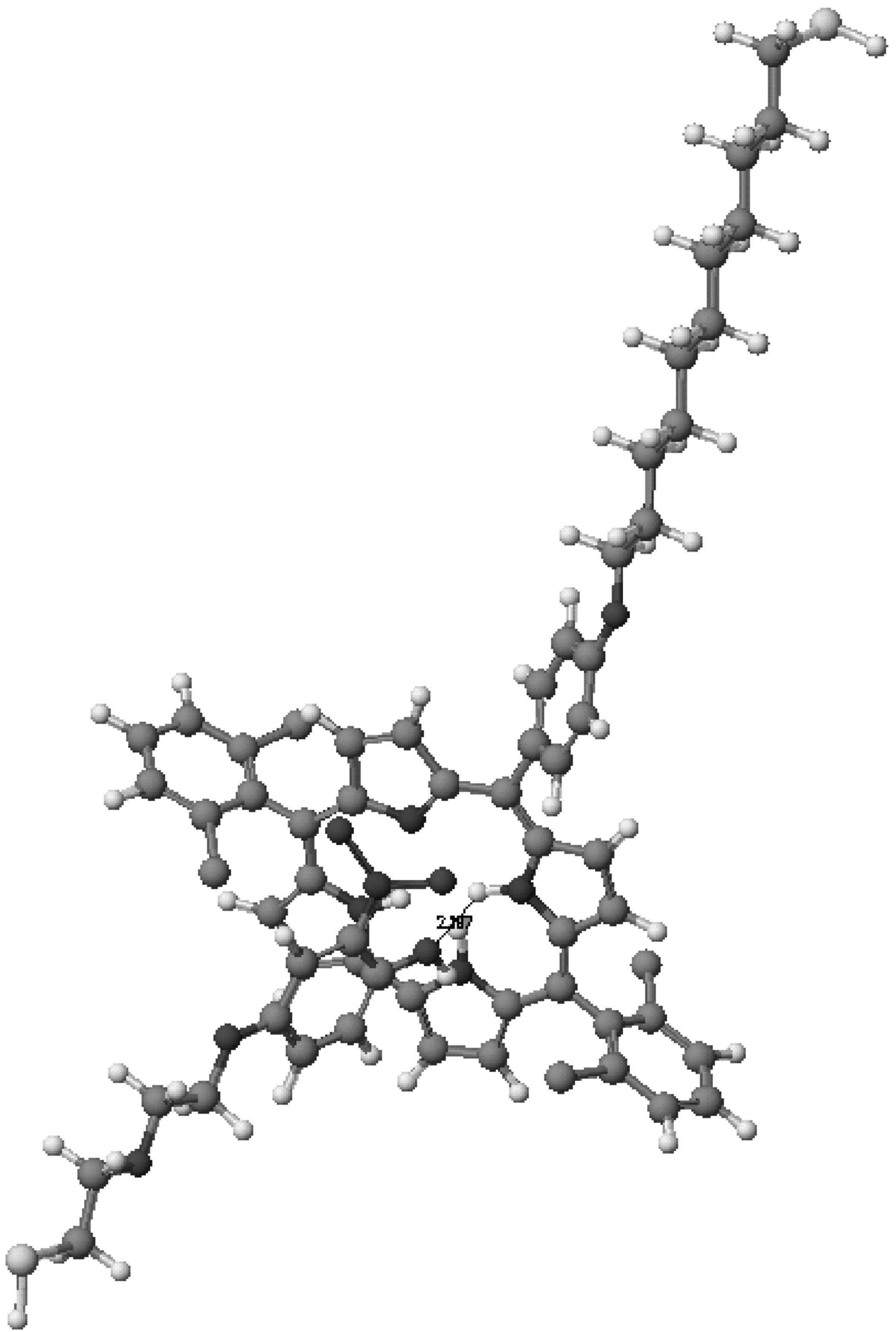


Determination of Interaction Strength between Corrole and Phenol Derivatives in Aqueous Media Using Atomic Force Microscopy

\author{
Iwona Szymańska ${ }^{1}$, Eddy Dolusic ${ }^{2}$, Wim Dehaen², Wouter Maes ${ }^{2}$, \\ Takashi Ito $^{3^{*}}$, Hanna Radecka ${ }^{1^{*}}$ \\ ${ }^{1}$ Institute of Animal Reproduction and Food Research of Polish Academy of Sciences, \\ Tuwima 10, 10-747 Olsztyn, Poland \\ ${ }^{2}$ University of Leuven, Department of Chemistry, Celestijnenlaan 200F, Leuven, 3030 \\ Heverlee, Belgium \\ ${ }^{3}$ Kansas State University, Department of Chemistry, 111 Willard Hall, Manhattan KS 66506- \\ 3701, USA \\ * corresponding authors: hanna.radecka@pan.olsztyn.pl; ito@ksu.edu
}




\begin{abstract}
Atomic force microscopy (AFM) was used to measure single interaction forces between corrole (host) and phenol derivatives (guests) in aqueous media. A gold tip was modified with thiol derivatives of corrole via the Au-S covalent bond. Such a tip was used to measure adhesion forces with a planar gold substrate modified with thiol-derivatives of phenol and ortho-nitrophenol in aqueous solutions. The mean force between the corrole and orthonitrophenol was higher than that between corrole and phenol, probably reflecting stronger hydrogen bond interaction in the former complex. In the presence of supporting electrolyte (0.1 $\left.\mathrm{M} \mathrm{K}_{2} \mathrm{SO}_{4}\right)$, the mean force increased, suggesting that electrostatic and $\pi-\pi$ interactions play an essential role in the adhesion force. In addition, adhesion force measured at $\mathrm{pH} 6.0$ was larger than that at $\mathrm{pH} 10$, reflecting the electrostatic repulsion at the higher $\mathrm{pH}$. These behaviors are consistent with the potentiometric responses of a liquid membrane based on corrole to phenolic compounds. Also, the values of forces for interaction between corrole phenol derivatives showed the same tendency as energy calculated for these complexes. The Poisson method was used for the calculation of the single force of the chemical bond between the corrole host and the phenolic guests.
\end{abstract}

Keywords: atomic force microscopy, molecular recognition, corrole, phenol derivatives, aqueous media

\title{
INTRODUCTION
}

The exploring of the mechanism of the host - guest recognition at the molecular level is a valuable source of inspiration for researchers dealing with sensors which are working by mimicking physiological processes occurring with outstanding sensitivity and selectivity. The source of the intensive development of the above study is a new research field, nanoscience, 
which deals with the objects as small as $1-100 \mathrm{~nm}$ [1-2]. Images of surfaces at such an extremely small scale, down to resolving individual atoms or molecules, can be obtained by newly developed technologies, namely scanning tunneling microscopy (STM) and atomic force microscopy (AFM) [3 - 9]. The introduction of chemically tailored STM tips by Umezawa and co-workers dramatically improved the sensitivity of visualization of molecular recognition processes at the membrane/solid interfaces [10-18]. The chemical modification of STM tips [10-18] as well as AFM tips [19, 20] increases the chemical affinity between the imaging tip and the substrates through formation of hydrogen bonds, metal - coordination bonds and charge - transfer interactions. This remarkable cutting-edge technique has opened the possibility to explore the host -guest interactions at the molecular level between nucleobases [18], drug - enzyme [21], antigen - antibody [22, 23], and other biomolecules $[24,25]$, just to name a few.

The main objective of the research presented is showing the applicability of the AFM method together with chemically tailored tips for the exploring of the molecular recognition processes between corroles and phenol derivatives occurring at the solid /aqueous interface.

It has been already discovered by the potentiometric method that liquid membrane electrodes incorporating macrocyclic polyamines [26-29], calix[4]pyrroles [30-33] or corroles [34-35] upon stimulation with undissociated phenol derivatives generated potentiometric responses. The mechanism of this unusual phenomenon, generation of potentiometric signals by neutral molecules, relies on the transport of protons from the interface to the aqueous layer adjacent to the organic phase.

The host molecule being the subject of this study is corrole. This molecule belongs to the tetrapyrrolic macrocyclic compounds with $18 \pi$ electrons. Corroles contain one direct linkage between two adjacent pyrrole rings. They display unusually high N-H acidity relative to other related macrocycles [36]. 
In this paper we present a study on the interaction forces between corrole and phenol derivatives immobilized through Au-S bonds on a gold AFM tip and a gold substrate surface, respectively. The influence of the $\mathrm{pH}$ and the composition of aqueous solution on the strength of these interactions was also explored. These experiments have addressed to determination of type of forces between corrole host and phenolic guests, measured in aqueous media.

\section{EXPERIMENTAL \\ Materials and Reagents}

The gold tip and substrates modification together with the chemical structures of the corrole and phenol derivatives used in the present study are illustrated in Scheme 1. Phenol, and ortho - nitrophenol possessing SH group were received from ProChimia Surfaces (Sopot, Poland). Planar gold substrates (Au.1000.ALSI) were purchased from Platypus Technologies (Madison, USA). AFM cantilevers, commercially available (contact mode, resonant frequency $13 \mathrm{kHz}$, force constant $0.2 \mathrm{~N} / \mathrm{m}$ ) were obtained from Budgetsensors (Sofia Bulgaria). All aqueous solutions were prepared with deionized water purified with a Milli-Q water system. All the chemicals were analytical grade, used as received.

\section{Synthesis of corrole}

Corrole was synthesized at the Department of Chemistry (University of Leuven) using method [37-39] as described below:

\section{4-(10-Undecenoxy)benzaldehyde}

A mixture of $7.030 \mathrm{~g}$ (28.64 mmol) of 11-bromo-1-undecene, $4.892 \mathrm{~g}$ (39.66 mmol) of p-hydroxybenzaldehyde and $8.328 \mathrm{~g}(60.26 \mathrm{mmol})$ of potassium carbonate was heated at reflux in $105 \mathrm{ml}$ of acetone (p.a.) for $15 \mathrm{~h}$. Upon cooling, the reaction mixture was filtered, evaporated to dryness and the residue was taken into dichloromethane. The solution was washed three times with aqueous $\mathrm{NaOH}$, then three times with water and dried over $\mathrm{MgSO}_{4}$. 
Upon filtration and removal of $\mathrm{CH}_{2} \mathrm{Cl}_{2}$ by distillation under reduced pressure, product $\mathbf{1 5 2}$ was purified by column chromatography on silica. Eluting with 1:1 dichloromethane / light petroleum ether afforded $7.450 \mathrm{~g}(95 \%)$ of the title product. $\delta_{\mathrm{H}}(300 \mathrm{MHz}) 9.88(\mathrm{~s}, 1 \mathrm{H}$, aldehyde H), 7.82 (d, $J$ 8.1, 2H, aryl H), 6.99 (d, $J$ 8.1, 2H, aryl H), 5.81 (m, 1H, undecenyl 10-H), 4.97 (m, 2H, undecenyl 11-H) $4.04(\mathrm{t}, J$ 6.6, 2H, undecenyl 1-H), 2.04 (q, J 7.0, 2H, undecenyl H), 1.81 (quintet, J 7.0, 2H, undecenyl 2-H), $1.46-1.31$ (m, 12H, undecenyl H).

\section{4-(11-Thioacetoxyundecyl)benzaldehyde}

4-(10-Undecenoxy)benzaldehyde $(7.450 \mathrm{~g} ; 27.15 \mathrm{mmol})$, thioacetic acid (4 ml; 56.23 mmol) and azo-bis-isobutyronitrile $(229 \mathrm{mg} ; 1.37 \mathrm{mmol})$ were dissolved in $90 \mathrm{ml}$ of toluene (p.a.). The mixture was degassed with a stream of argon and then refluxed for $6.5 \mathrm{~h}$. The reaction was quenched with $5 \%$ aqueous $\mathrm{NaHCO}_{3}(400 \mathrm{ml})$ and extracted three times with ethyl acetate. The combined organic layers were washed with $5 \%$ aqueous $\mathrm{NaHCO}_{3}$, then brine and dried over $\mathrm{MgSO}_{4}$. Upon filtration and removal of the solvent under reduced pressure, the yellow solid residue was chromatographed on silica eluting with a gradient of 5:1 to 1:1 light petroleum ether / ethyl acetate. The crude product obtained was recrystallized from methanol to afford $4.086 \mathrm{~g}(43 \%)$ of a white powder. $\delta_{\mathrm{H}}(300 \mathrm{MHz}) 9.88(\mathrm{~s}, 1 \mathrm{H}$, aldehyde H), $7.83(\mathrm{~d}, J$ 8.6, 2H, aryl H), $6.99(\mathrm{~d}, J$ 8.6, 2H, aryl H), $4.04(\mathrm{t}, J$ 6.6, 2H, undecenyl 1-H), $2.86\left(\mathrm{t}, J\right.$ 7.3, 2H, undecenyl 11-H), $2.32\left(\mathrm{~s}, 3 \mathrm{H}, \mathrm{CH}_{3}\right), 1.81$ (quintet, $J$ 7.3, $2 \mathrm{H}$, undecenyl 2-H), $1.46-1.28\left(\mathrm{~m}, 16 \mathrm{H}, 8 \mathrm{CH}_{2}\right)$.

\section{Meso-5,15-bis(2,6-dichlorophenyl)-10-(4-(11-thioacetoxy-1-dodecyloxy) phenyl)corrole}

2,6-Dichlorophenyldipyrromethane (1.522 g; $5.23 \quad \mathrm{mmol})$ and 4-(11thioacetoxyundecyl)benzaldehyde (606 $\mathrm{mg} ; 1.73 \mathrm{mmol})$ were dissolved in $146 \mathrm{ml}$ of dichloromethane. The reaction flask was wrapped in aluminium foil and placed in an ice bath. 
The solution was bubbled with Ar for $15 \mathrm{~min}$. Ten $\square$ l of TFA (0.13 mmol) was added and the mixture was stirred under an argon atmosphere for $\sim 48 \mathrm{~h}$. The ice bath was removed and 935 $\mathrm{mg}(3.77 \mathrm{mmol})$ of $p$-chloranil was added. After additional $1 \mathrm{~h}$ at room temperature, the mixture was evaporated with silica and chromatographed twice in a 1.5:1 mixture of dichloromethane and $n$-heptane to afford $452 \mathrm{mg}(29 \%)$ of corrole. $\delta_{\mathrm{H}} 9.00(\mathrm{~d}, J 4.1,2 \mathrm{H}, 2-\mathrm{H}$ and $18-\mathrm{H}$ of corrole), 8.62 (d, $J$ 4.7, 2H, 8- H and 12-H of corrole), 8.53 (d, $J 4.7,2 \mathrm{H}, 7-\mathrm{H}$ and 13-H of corrole), 8.42 (d, $J 4.1,2 \mathrm{H}, 3-\mathrm{H}$ and 17-H of corrole), $8.08(\mathrm{~d}, J 8.5,2 \mathrm{H}$, aryl $o-\mathrm{H})$, $7.78(\mathrm{~d}, J$ 7.7, 4H, dichlorophenyl $m-\mathrm{H}), 7.66\left(\mathrm{dd}, J_{1} 7.7, J_{2} 8.7,2 \mathrm{H}\right.$, dichlorophenyl $p$-H), 7.27 (d partially overlapped with $\mathrm{CHCl}_{3}, J 8.5,2 \mathrm{H}$, aryl $m-\mathrm{H}$ ), $4.24\left(\mathrm{t}, J 6.5,2 \mathrm{H}, \mathrm{OCH}_{2}\right.$ ), 2.89 (t, J 7.3, 2H, $\mathrm{SCH}_{2}$ ), 2.32 (s, 3H, $\mathrm{CH}_{3}$ ), 1.98 (quintet, $J$ 7.4, $2 \mathrm{H}, \square-\mathrm{CH}_{2}$ ), $1.62-1.36(\mathrm{~m}, 16 \mathrm{H}$, $8 \mathrm{CH}_{2}$ ), -2.30 (br. s, $3 \mathrm{H}, \mathrm{NH}$ ); $\delta_{\mathrm{C}} 196.0,158.9,138.6$ (quaternary C), 137.4 (quaternary C), $135.5(\mathrm{CH}), 134.0$ (quaternary C), 130.3 (dichlorophenyl $p$-C), 128.0 (dichlorophenyl $m$-C), 127.2 (pyrrole $\mathrm{CH}$ ), 125.7 (pyrrole $\mathrm{CH}$ ), 120.8 (C-3 and C-17 of corrole), 116.2 (C-2 and C18 of corrole), $113.2(\mathrm{CH}), 111.7$ (quaternary C), 108.8 (quaternary C), 68.3, 30.6, 29.6, 29.5, 29.1, 28.8, 26.2; UV-Vis $410.1\left(1.35 \cdot 10^{5}\right), 566.1\left(0.22 \cdot 10^{5}\right)$; ESI-MS $907\left(\mathrm{MH}^{+}\right)$.

\section{Meso-5,15-bis(2,6-dichlorophenyl)-10-(4-(11-mercapto-1-dodecyloxy) phenyl)corrole}

Acetyl protected corrole (130 mg; $0.14 \mathrm{mmol}$ ) was dissolved in $7.5 \mathrm{ml}$ of THF and $3 \mathrm{ml}$ of methanol. The flask was placed in an ice bath and $1 \mathrm{ml}$ of a $1.65 \mathrm{M}$ solution of $\mathrm{CH}_{3} \mathrm{ONa}$ in methanol $\left(1.65 \mathrm{mmol}\right.$ of $\left.\mathrm{CH}_{3} \mathrm{ONa}\right)$ was added. The reaction mixture was stirred at $0^{\circ} \mathrm{C}$ for 30 min and then poured into diluted aqueous $\mathrm{HCl}(\sim 0.02 \mathrm{M})$. This solution was extracted with ethyl acetate (some brine had to be added for a better separation) and then washed with brine, distilled water and dried over $\mathrm{MgSO}_{4}$. Upon filtration and removal of the solvent under reduced pressure, $26 \mathrm{mg}(21 \%)$ of corrole thiol was isolated by chromatography in mixtures of $\mathrm{CH}_{2} \mathrm{Cl}_{2}$ and hexane (1.5:1, column and 1:1, preparative plate). $\delta_{\mathrm{H}} 8.97(\mathrm{~d}, J 3.9,2 \mathrm{H}, 2-\mathrm{H}$ 
and 18-H of corrole), 8.61 (d, $J 4.5,2 \mathrm{H}, 8-\mathrm{H}$ and 12-H of corrole), 8.51 (d, $J 4.5,2 \mathrm{H}, 7-\mathrm{H}$ and 13- $\mathrm{H}$ of corrole), 8.39 (d, $J 3.9,2 \mathrm{H}, 3-\mathrm{H}$ and 17- $\mathrm{H}$ of corrole), $8.07(\mathrm{~d}, J 8.2,2 \mathrm{H}$, aryl $o-\mathrm{H})$, $7.72(\mathrm{~m}, 4 \mathrm{H}$, dichlorophenyl $m-\mathrm{H}), 7.59\left(\mathrm{dd}, J_{1} 8.3, J_{2} 8.3,2 \mathrm{H}\right.$, dichlorophenyl $\left.p-\mathrm{H}\right), 7.24(\mathrm{~d}$ partially overlapped with $\mathrm{CHCl}_{3}, J 8.2,2 \mathrm{H}$, aryl $m$-H), $4.20\left(\mathrm{t}, J 6.4,2 \mathrm{H}, \mathrm{OCH}_{2}\right), 2.50(\mathrm{t}, J$ 6.8, 2H, $\mathrm{SCH}_{2}$ ), 1.93 (quintet, $2 \mathrm{H}, \square-\mathrm{CH}_{2}$ ), 1.60 (m, $4 \mathrm{H}, 2 \mathrm{CH}_{2}$ ), $1.39-1.26\left(\mathrm{~m}, 13 \mathrm{H}, 6 \mathrm{CH}_{2}\right.$ and $\mathrm{SH}), \sim-1.9$ (br. s, 3H, NH); $\delta_{\mathrm{C}} 158.8(\mathrm{CO}), 142.1$ (9-C and 11-C of corrole), 139.8 (6-C and 14-C of corrole), 138.5, 137.4, 135.5, 134.6, 134.0, 130.7, 130.3, 128.0 (3-C and 5-C of 5,15-dichlorophenyl), 127.1, 125.7 (8-C and 12-C of corrole), 120.8 (A and D ring $\square$-pyrrole C), 116.2 (A and D ring $\square$-pyrrole C), 113.2 (A and D ring $\square$-pyrrole C), 111.7 (5-C and 15C of corrole), 108.9 (10-C of corrole); ESI-MS $865\left(\mathrm{MH}^{+}\right)$.

\section{Formation of SAMs on gold substrates and gold tips}

Before the modification the substrates were sonicated for 10 minutes in ethanol, dried with argon and annealed in a hydrogen flame. Next, the gold substrates were immersed in 10 $\mathrm{mM}$ ethanolic solutions of derivatives of phenol $(\mathbf{P h})$ and nitrophenol $\left(\mathbf{P h N \mathbf { O } _ { 2 }}\right)$, for 20 hours. Next, the substrates were rinsed with ethanol and water and dried in air. At least, 3 repetitions of the substrate modification samples were done.

The gold tips were washed with ethanol, pretreated in an UV/ozone chamber (Novascan Technologies, Ames, USA) for $30 \mathrm{~min}$., and then immersed in $0.5 \mathrm{mM}$ corrole (COR) chloroform solution for 24 hour. Thus, 5 tips were modified and used for the experiments.

\section{AFM measurements}

AFM measurements were carried out with a Molecular Imaging PicoSPM (Agilent Technologies, Tempe, USA). Substrates: $\mathrm{Ph}$ or $\mathrm{PhNO}_{2}$ and cantilever COR/tip were loaded in a liquid cell, which was allowed to reach thermal equilibrium before starting the AFM 


\section{RESULTS AND DISCUSSION}

Strength of adhesion forces between the corrole host and the phenolic guests measured in water by AFM

The experiments to study the interactions between the corrole host and the phenolic guests were carried out by using modified gold substrates and tips. The modification procedures are illustrated in Scheme 1.

First, interactions between a COR/tip and $\mathrm{Ph}$ - or $\mathrm{PhNO}_{2}$-substrates were assessed in water at room temperature. The tip and substrate were mounted in liquid cell and the force displacement curves were monitored. Figure 1 shows a typical force-displacement curve observed between a $\mathrm{PhNO}_{2}$-substrate and a COR/tip. In many measurements, an adhesion force as shown in the Figure 1 was observed in the retracting part of the curve. In this paper, the host-guest interactions in water will be verified based on adhesion force, since it has often been used to discuss various intermolecular interactions [40]. Adhesion forces obtained from multiple measurements using a single tip on different locations of a sample were summarized in a histogram, which show the probability of a given value of adhesion forces. Figure $2 \mathrm{~A}$ and Figure 3A show histograms observed with a COR/tip on a $\mathrm{PhNO} 2$-substrate and a $\mathrm{Ph}$ - 
substrate, respectively. The average of adhesion force, measured using multiple COR/tips, was slightly larger for the $\mathrm{PhNO}_{2}$-substrates $(2.1 \pm 0.5 \mathrm{nN})$ in comparison with the $\mathrm{Ph}$ substrate $(1.7 \pm 0.3 \mathrm{nN})($ Table 1$)$

In order to assess the contribution of nonspecific interactions to the aforementioned adhesion force data, force-distance curves on $\mathrm{Ph}$ - or $\mathrm{PhNO}_{2}$ - substrates were measured using unmodified gold tip. Figure 4A and 4B shows histograms obtained from adhesion force data for a single tip. The adhesion forces were $1.0 \pm 0.2 \mathrm{nN}$ and $0.7 \pm 0.2 \mathrm{nN}$, for $\mathrm{Ph}-$ and $\mathrm{PhNO}_{2}$ substrates, respectively. These values were smaller than those obtained with COR-tip. In addition, bare gold tips gave slightly larger adhesion force on $\mathrm{Ph} /$ substrates whereas COR-tips gave larger force on $\mathrm{PhNO}_{2} /$ substrate. These results suggest that the difference in adhesion force measured using COR-tips reflects from the host-guest interactions.

The adhesion force reported above reflects not only the host-guest interactions but also the contact area originating from the variation in tip size [41]. The pull - off features in the retracting part of the force - distance curve can be used to calculate also the strength of a single chemical bond [42-46], which is not affected by the variation of the contact area. It has already been reported that AFM contact forces obeyed a Poisson distribution. Thus, the ratio of their variance to the mean gives the force of a single chemical bond between the tip and the substrate. The Poisson method requires relatively few measurements. By plotting a linear regression curve of the variance vs. the mean force taken from several sets of AFM measurements done at different locations on the surface and different tips, the magnitude of the individual bond force can be estimated. The lack of assumptions about the tip radius is another important advantage of this method. Indeed, the Poisson statistical analysis method has been widely used for the calculation of individual bond forces between the AFM tip and the substrate, both functionalized [42-46]. Thus, the Poisson method was used in the present study for the evaluation of the strength of single molecule bond forces between corrole and 
phenol or ortho - phenol derivatives. Corroles due to the steric hindrance create less packed monolayers on the surface. Moreover, because of presence of short ethylene chains, the phenol derivatives SAMs are less ordered. These factors cause that the density of the host and guest on the surface is rather low. Thus, the Poisson method is suitable for the systems studied.

From the slope of the linear relationship between the mean force and its variance, the single molecule bond force can be calculated (Figure 2B, Figure 3B). The calculated single molecule bond forces were $16 \pm 3 \mathrm{pN}$ for the $\mathrm{Ph}$ - and $75 \pm 11 \mathrm{pN}$ for the $\mathrm{PhNO}_{2}$-substrate, respectively (Table 2). Thus, the strength of the individual bond force between corrole and ortho-nitrophenol was almost five times higher in comparison with the force between corrole and phenol. These values are in a similar range as reported by Beebe Jr. et al. [42] and Hadziioannou et al. [47]. Their reports deal with a study of the hydrogen bonding, van der Waals and Coulombic interactions between $\omega$ - functional $n-$ alkanethiol compounds with a variety of functional groups $\left(\mathrm{CH}_{3}, \mathrm{OH}, \mathrm{NH}_{2}, \mathrm{COOH}\right.$ and $\left.\mathrm{CONH}_{2}\right)$ which were used for modification of scanning force microscopy probes and substrates.

\section{pH dependence on the strength of the adhesion forces between the corrole host and the phenolic guests measured in $0.1 \mathrm{M} \mathrm{K}_{2} \mathrm{SO}_{4}$ by the AFM method}

In order to explore the influence of the $\mathrm{pH}$ and the electrolyte on the strength of interactions between the host and guests studied, subsequent experiments were done in the presence of $0.1 \mathrm{M} \mathrm{K}_{2} \mathrm{SO}_{4}$ at two $\mathrm{pH}$ values: 6.0 and 10.0.

At $\mathrm{pH}$ 6.0, the shape of force-distance curves was similar to that observed in water (Figure 1). At that $\mathrm{pH}$, corrole exists as a mixture of electrically neutral and deprotonated 
molecules on the surface of the gold tip [34]. On the other hand, the phenol and orthonitrophenol derivatives exist as the undissociated compound [31, 32].

The histograms for the adhesion forces obtained for COR/tip and $\mathrm{Ph}$ - or $\mathrm{PhNO}_{2}$ substrate measured at $\mathrm{pH} 6.0$ and their corresponding plots of mean force vs variance are given in Figures 5 and 6. The average of adhesion force of COR-tips with $\mathrm{PhNO}_{2} /$ substrates $(5.0 \pm 0.8 \mathrm{nN}$; Figure 5A and Table 1) is twice larger than that with $\mathrm{Ph} /$ substrates $(2.2 \pm 0.6$ $\mathrm{nN}$; Figure 5A and Table 1). The single bond force between corrole and $\mathrm{PhNO}_{2}$ was also larger $(140.5 \pm 33.0 \mathrm{pN}$; Figure 5B and Table 2$)$ than that between corrole and $\mathrm{Ph}(59.3 \pm 10$ $\mathrm{pN}$; Figure $6 \mathrm{~B}$ and Table 2). This result is again consistent with the stronger interactions between the corrole molecules and ortho-nitrophenol in comparison with phenol.

Adhesion force between the tip modified with corrole and substrates was not observed at pH 10 (Figure 7). Recorded force - distance curves displayed the typical shape for the repulsive forces between the functionalized tip and surface [40]. This lack of adhesion force is mainly caused by electrostatic repulsion between the tip and substrate. At $\mathrm{pH}$ 10.0, both corrole molecules and phenol and ortho-nitrophenol derivatives exist in the negatively charged forms. The $\mathrm{pK}_{\mathrm{a}} \mathrm{s}$ of ortho-nitrophenol and phenol are 7.21 and 10.0, respectively. Thus, at $\mathrm{pH} 10.0$, both the host and guests molecules obtain a negative charge.

Similar phenomena, namely the switching in binding forces in relation to a change of the $\mathrm{pH}$, were observed in several studies. The deprotonation effect of the ammonium group on the surface of the substrate under basic condition caused a decrease in the interaction between ammonium ion complexes with crown ethers moiety as presented by Kimura et al. [48]. A decrease in adhesion force with increased $\mathrm{H}^{+}$concentration for amino - or 2 - imidazolin - 1 -yl terminated SAMs is a result of the repulsion between the positively charged tip and the substrate surfaces as reported by Umezawa et al. [49]. In the present study, we have demonstrated that the individual interaction forces between corrole and phenol as well as 


\section{Computer simulation on the complexation between corrole and phenols}

In addition, the difference in adhesion force observed for $\mathrm{PhNO}_{2}$ - and $\mathrm{Ph}$ - substrate would originate from hydrogen bond interactions with corrole. The creation of supramolecular assemblies is controlled by $\mathrm{N}-\mathrm{H} \cdots \mathrm{X}$ and $\mathrm{O}-\mathrm{H} \cdots \mathrm{X}(\mathrm{X}=\mathrm{O}, \mathrm{N})$ hydrogen bonds. The majority of recent publications are connected with molecular complexes of phenolic substrates with a variety of receptors $[50,51]$. These reports show that the supramolecular assembly is controlled by strong and directional $\mathrm{O}-\mathrm{H} \cdots \mathrm{N}$ hydrogen bonds. The phenolic compounds can create a supramolecular complex with corrole [33, 34]. The interaction involves the creation of a hydrogen bond between the $\mathrm{NH}$ group of the macrocyclic cavity of the corrole and the $\mathrm{OH}$ group of the phenol derivative. The oxygen from the phenolic host is an acceptor of hydrogen, while the $\mathrm{NH}$ group is a donor of hydrogen.

The significance of the hydrogen bond interactions in the host-guest supramolecular complex was verified using AM1 geometry procedure (MOPAC 2002 Version 2.5.3, J. J. P. 
Stewart, Fujitsu Limited, Tokyo, Japan). The calculation of a number of different conformations of the corrole and guest compounds was done using the CaChe Workspace programme in vacuum (CaChe Worksystem Pro Version 7.5.0.85). In Scheme 2, a model of the complex formation between corrole and ortho - nitrophenol derivatives is presented, as optimized by the AM1 geometry procedure. However, the calculation showed that the binding energy of ortho - nitrophenol is in a range of $-5.8 \mathrm{kcal} / \mathrm{mol}$. On the other hand, the phenol binding strength is a little less energetically favorable $(-3.5 \mathrm{kcal} / \mathrm{mol})$. In order to correlate the energy binding and force of the complex formation of corrole with phenol and ortho nitrophenol, the procedure described by Reinhoudt was applied [52]. In this procedure, the dependence of pull-off forces vs. energy was achieved for the spherical and cylindrical integration approaches, according the following equations: $\mathrm{F}=32.60 \mathrm{x} \sqrt{-\Delta G+2.39}$ or $\mathrm{F}=$ 31.76x $\sqrt{-\Delta G+1.03}$, respectively (with $-\Delta \mathrm{G}$ in $\mathrm{kcal} / \mathrm{mol}$ and $\mathrm{F}$ in $\mathrm{pN}$ ). Taking into account cylindrical integration approaches, the calculated values of forces were $83.0 \mathrm{pN}$ and $67.6 \mathrm{pN}$, for $\mathrm{PhNO}_{2}$ and $\mathrm{Ph}$, respectively. The difference between predicted and experimental values is therefore as follows: $83.0 / 140.5$ and $67.6 / 59.3 \mathrm{pN}$, respectively, as compared for the values obtained in $0.1 \mathrm{~K}_{2} \mathrm{SO}_{4}, \mathrm{pH}$ 6.0. The differences between calculated and experimental data could be caused by possible contribution of other kind of forces (e.g. $\pi-\pi$ interactions or hydratation of water molecules to the complex). However, the results of calculation show the similar tendency as experimental data described in this paper.

The results obtained using AFM together with a chemically modified tip also correlate well with those obtained potentiometricaly, which concern the studies of corroles as the selective receptors for phenol derivatives existing as the electrically neutral analytes [33-35]. The presence of a nitro group on the benzene ring increases the acidity of the phenolic $\mathrm{OH}$ group, and as a consequence, a stronger potentiometric signal was observed. The significant part of the recognition process is the formation of weak hydrogen bonds between the electron 


\section{CONCLUSIONS}

We presented a study on the strength of the interactions between a corrole host and phenolic guests using the AFM method together with gold substrates and tips modified with SAMs thorough Au-S covalent bonds. The specific intermolecular forces between corrole covalently immobilized on the gold AFM tip and derivatives of phenol, also attached via a sulfur - gold bond to the surface of substrates was observed by means of atomic force microscopy. The dominant nature in the selectivity of interactions between corrole host and phenolic guest are hydrogen bonds. Also, hydrophobic and $\pi-\pi$ interactions between phenol and pyrrole rings are involved. The strength of the single adhesion forces between corrole host and phenolic guest were determined by the Poissson method analysis. The sequence of the strength of the single bond force obtained with the AFM method correlate well with the calculated values of energy and the selectivity of potentiometric signals obtained by liquid membrane electrodes incorporating corrole after stimulation with neutral phenolic guests [3335]. The results obtained confirm the possibility to apply the atomic force microscopy for the observation at the molecular level of the creation of supramolecular complexes between nitrogen containing macrocycles and uncharged phenol derivatives. Notably, the nitrophenol isomers were recently identified as vasodilators which can mimic hormones, and can be considered as endocrine disrupting chemicals possessing estrogenic activity [53]. Thus, looking for the compounds which could specifically bind these molecules is very important from the theoretical and practical point of view. On the other hand, taking into account the interesting features of corrole which might be protonated and associate with a low $\mathrm{pH}$ cancer 
cell, these molecules can be used as sensors in biological systems and therefore there is still need for basic research connected with analogous systems.

\section{Acknowledgements}

We gratefully acknowledge financial support from the Kościuszko Foundation (to I. S.), EU grant COST D31/0021/05 (to I. S., H. R., E. D., W. D., W. M), Polish Ministry of Science and Higher Education 19/COS/2006/3 (to I. S. and H. R.), the F.W.O, the University of Leuven and the Ministerie voor Wetenschapsbeleid (to E. D., W. D., W. M.) and Kansas State University (to T.I.).

\section{References}

[1] Joachim, C. Nat. Mater. 2005, 4, 107.

[2] Love, J. Ch.; Estroff, L. A.; Kriebel, J. K.; Nuzzo, R. G.; Whitesides, G. M. Chem. Rev. 2005, 105, 1103.

[3] Skoog, D. A.; Holler, F. J.; Nieman, T. A. Thomson Learning, Fifth Edition, 1998.

[4] Sugimoto, Y.; Abe, M.; Hirayama, S.; Oyabu, N.; Custance, O.; Morita S. Nat. Mater. 2005, 4, 156.

[5] Kuffer, O. R.; Maggio - Aprile, I.; Fisher, O. Nat. Mater. 2005, 4, 378.

[6] Mikkelsen, A.; Skold, N.; Ouattara, L.; Borgstrom, M.; Andersen, J. N.; Samuelson, L.; Seifert, W.; Lundgren, E. Nat. Mater. 2004, 3, 519.

[7] Tromas, Ch.; Eaton, P.; Mimault, J.; Rojo, J.; Penadés, S. Langmuir 2005, 21, 6142.

[8] Podoprygorina, G.; Janke, M., Janshoff, A., Bohmer V. Supramol. Chem. 2008, $20,59$.

[9] Sansone, F.; Baldini, L.; Casnati, A.; Ungaro, R. Supramol. Chem. 2008, 20, 161.

[10] Ito, T.; Bühlmann, P.; Umezawa,Y. Anal. Chem. 1998, 70, 255.

[11] Ito, T.; Bühlmann, P.; Umezawa,Y. Anal. Chem. 1999, 71, 1699.

[12] Nishino, T.; Bühlmann, P.; Ito, T.; Umezawa,Y. Phys. Chem. Chem. Phys. 2001, 3, 1867.

[13] Nishino, T.; Bühlmann, P.; Ito, T.; Umezawa,Y. Surf. Sci. 2001, 490, L579. 
[14] Odashiro, T.; Ito, T.; Bühlmann; Umezawa,Y. Anal. Chem. 2001, 73, 878.

[15] Nishino, T.; Ito, T.; Umezawa,Y. Anal. Chem. 2002, 74, 4275.

[16] Nishino, T.; Ito, T.; Umezawa,Y. J. Electroanal. Chem. 2003, 550, 125.

[17] Nishino, T.; Ito, T.; Umezawa,Y. Proc. Natl. Acad. Sci. U.S.A. 2005, 102, 5659.

[18] Ohshiro, T.; Umezawa,Y. Proc. Natl. Acad. Sci. U.S.A. 2006, 103, 10.

[19] Han, T.; Williams, J. M.; Beebe Jr., T. P. Anal. Chim. Acta 1995, 307, 365.

[20] Ito, T.; Namba, M.; Buhlmann, P.; Umezawa, Y. Langmuir 1997, 13, 4323.

[21] Rigby-Singleton, S. M.; Allen, S.; Davies, M. C.; Roberts, C. J.; Tendler, S. J. B.; Williams, P. M. J. Chem. Soc. Perkin Sens. 2002, 2, 1722.

[22] Browning-Kelley, M. E.; Wadu-Mesthrige, K.; Hari, V.; Liu, G. Y. Langmuir 1997, 13, 343.

[23] Avci, R.; Schweitzer, M.; Boyd, R. D.; Wittmeyer, J.; Steele, A.; Toporski, J.; Beech, I.; Teran Arce, F.; Spangler, B.; Cole, K. M.; McKay, D. S. Langmuir 2004, 20, 11053.

[24] Basnar, B.; Elnathan, R.; Willner, I. Anal. Chem. 2006, 78, 3638.

[25] Janshoff, A.; Neitzert, M.; Oberdorfer, Y.; Fuchs, H. Angew. Chem,. Int. Ed. 2000, 39, 3212.

[26] Piotrowski, T.; Szymańska I.; Radecka, H.; Radecki J.; Pietraszkiewicz, M.; Pietraszkiewicz O.; Wojciechowski K. Electroanalysis 2000, 12, 1397.

[27] Ito, T.; Radecka, H.; Tohda K., Odashima K.; Umezawa Y. J. Am. Chem. Soc. 1998, 120, 3049.

[28] Ito, T.; Radecka, H.; Umezawa K.; Kimura T.; Yashiro A.; Lin, X. M.; Kataoka, M.; Kimura E.; Sessler J. L.; Odashima K.; Umezawa Y. A. Anal. Sci. 1998, 14, 89.

[29] Odashima, K.; Naganawa, R.; Radecka, H.; Kataoka, M.; Kimura, E.; Koike, T.; Tohda, K.; Tange, M.; Furuta, H.; Sessler, J.L.; Yagi, K.; Umezawa, Y. Supramol. Chem. 1994, 4, 101. 
[30] Piotrowski T.; Radecka H.; Radecki J.; Depraetere S.; Dehaen, W. Mater. Sci. Eng., C 2001, 18, 223.

[31] Piotrowski T.; Radecka H.; Radecki J.; Depraetere S.; Dehaen W. Electroanalysis 2001, 13,342 .

[32] Radecki, J.; Radecka, H.; Piotrowski, T.; Depraetere, S.; Dehaen W.; Plavec J. Electroanalysis 2004, 16, 2073.

[33] Radecki, J.; Dehaen, W. Comb. Chem. High Throughput Screening 2006, 9, 399.

[34] Radecki, J.; Stenka I.; Dolusic, E.; Dehaen, W.; Plavec, J. Comb. Chem. High Throughput Screening 2004, 7, 375.

[35] Radecki, J.; Stenka, I.; Dolusic, E.; Dehaen, W. Electrochim. Acta 2006, 51, 2282.

[36] Mahammed, A.; Gray, H. B.; Weaver, J.; Gross, Z. Tetrahedron Lett. 2003, 44, 2077.

[37] Asokan, C.V.; Smeets, S.; Dehaen, W. Tetrahedron Lett. 2001, 42, 4483.

[38] Maes, W.; Ngo, T. N.; Vanderhaeghen, J.; Dehaen, W. Org. Lett. 2007, 9, 3165.

[39] Rohand, T.; Dolusic, E.; Ngo, T. H.; Maes, W.; Dehaen, W. Arkivoc 2007, 307.

[40] Janshoff, A.; Neitzert, M.; Oberdorfer, Y.; Fuchs, H. Angew. Chem., Int. Ed. 2000, 39, 3212.

[41] Israelachvili, JN. Intermolecular and Surface Forces London: Academic; 1985.

[42] Han, T.; Williams, J. M.; Beebe Jr., T. P. Anal. Chim. Acta 1995, 307, 365.

[43] Stevens, F.; Lo, Y.-S.; Harris, J. M.; Beebe Jr., T. P. Langmuir 1999, 15, 207.

[44] Lo, Y.-S.; Zhu, Y.-J.; Beebe Jr., T. P. Langmuir 2001, 17, 3741.

[45] Lo, Y. - S.; Huefner, N. D.; Chan, W. S.; Stevens, F.; Harris, J. M.; Beebe Jr., T. P. Langmuir 1999, 15, 1373.

[46] Wenzler, L. A.; Moyes, G. L.; Raikar, G. N.; Hansen, R. L.; Harris J. M.; Beebe Jr., T. P. Langmuir 1997, 13, 3761.

[47] van der Vegte, E. W.; Hadziioannou, G. Langmuir 1997, 13, 4357. 
[48] Kado, S.; Yamada, K.; Kimura, K. Langmuir 2004, 20, 3259.

[49] Ito, T.; Citterio, D.; Buhlmann, P.; Umezawa, Y. Langmuir 1999, 15, 2788.

[50] Vishweshwar, P.; Nangia, A.; Lynch V. M CrystEngComm 2003, 5, 164.

[51] Ghosh, K.; Datta, M.; Frohlich, R.; Ganguly, N. C. J. Mol. Struct. 2005, 737, 201.

[52] Auletta, T.; de Jong, M. R., Mulder, A.; van Veggel, F. C. J. M.; Huskens, J., Reinhoudt, D. N.; Zou, S.; Zapotoczny, S.; Schonherr, H.; Vansco, G. J.; Kuipers, L. J. Am. Chem. Soc. 2004, 126, 1577.

[53] Furuta, Ch.; Suzuki, A. K.; Taneda, S.; Kamata, K.; Hayasi, H.; Mori, Y.; Li, Ch.; Watanabe, G.; Taya, K. Biol. Reprod. 2004, 70, 1527.

List of Figures and Tables:

\section{Scheme 1.}

Schematic representation of corrole - SH molecules (COR) immobilized on the surface of a gold AFM tip (A) and $\mathbf{P h}(\mathbf{B}), \mathbf{P h N O}_{2}$ (C) compounds immobilized on gold substrates.

\section{Scheme 2.}

Structure of the complex between corrole with an ortho - nitrophenol derivative optimized by AM1 geometry (CaChe Worksysem Pro Version 7.5.0.85).

\section{Figure 1.}

Typical force curves (line "B" -approaching, b line "A" - retracting) observed for $\mathrm{PhNO}_{2}$ substrates using COR/tip made in water.

\section{Figure 2.}

(A) Histogram of adhesion forces obtained from the repetitive force measurements between single $\mathbf{C O R} /$ tip and $\mathbf{P h} /$ substrate in water. (B) A plot of mean $v s$. variance of adhesion force measured for $\mathbf{P h} /$ substrates using five separate COR/tips in water. 


\section{Figure 3.}

(A) Histogram of adhesion forces obtained from the repetitive force measurements between single $\mathbf{C O R} /$ tip and a $\mathbf{P h N O} \mathbf{N}_{2} /$ substrate in water. (B) A plot of mean vs. variance of adhesion force measured for $\mathbf{P h N O} \mathbf{O}_{2} /$ substrates using three separate COR/tips in water.

\section{Figure 4.}

Histograms of adhesion forces $(n=300)$ obtained from the repetitive force measurements between a bare gold AFM tip and a $\mathbf{P h} /$ substrate $(\mathbf{A})$ and a $\mathbf{P h N O} \mathbf{O}_{2} /$ substrate $(\mathbf{B})$ in water.

\section{Figure 5.}

(A) Histogram of adhesion forces obtained from the repetitive force measurements between single COR/tip and a $\mathbf{P h} /$ substrate in $0.1 \mathrm{M} \mathrm{K}_{2} \mathrm{SO}_{4}(\mathrm{pH}$ 6.0). (B) A plot of mean vs. variance of adhesion force measured for $\mathbf{P h} /$ substrates using three separate COR/tips in $0.1 \mathrm{M} \mathrm{K}_{2} \mathrm{SO}_{4}$ (pH 6.0).

\section{Figure 6.}

(A) Histogram of adhesion forces obtained from the repetitive force measurements between single COR/tip and the $\mathbf{P h N O}_{2} /$ substrate in $0.1 \mathrm{M} \mathrm{K}_{2} \mathrm{SO}_{4}(\mathrm{pH} \mathrm{6.0)}$. (B) A plot of mean vs. variance of adhesion force measured for $\mathbf{P h N O}_{2} /$ substrates using four separate COR/tips in $0.1 \mathrm{M} \mathrm{K}_{2} \mathrm{SO}_{4}(\mathrm{pH}$ 6.0).

\section{Figure 7.}

Typical force curves (line "B" -approaching, b line "A" - retracting) observed for $\mathrm{PhNO}_{2}$ substrates using COR/tip made in $0.1 \mathrm{M} \mathrm{K}_{2} \mathrm{SO}_{4}$ at $\mathrm{pH} 10.0$.

\section{Table 1.}

Adhesion forces measured with unmodified and corrole-modified tips and gold substrates modified with $\mathrm{Ph}$ or $\mathrm{PhNO}_{2}$ in different aqueous solutions.

\section{Table 2.}


Single bond forces measured with corrole-modified tips and $\mathrm{Ph}$ and $\mathrm{PhNO}_{2}$ compounds immobilized on gold substrates in different aqueous solutions. 


\section{Scheme 1.}

Schematic representation of corrole - SH molecules (COR) immobilized on the surface of a gold AFM tip (A) and $\mathbf{P h}(\mathbf{B}), \mathbf{P h N O}_{\mathbf{2}}(\mathbf{C})$ compounds immobilized on gold substrates.

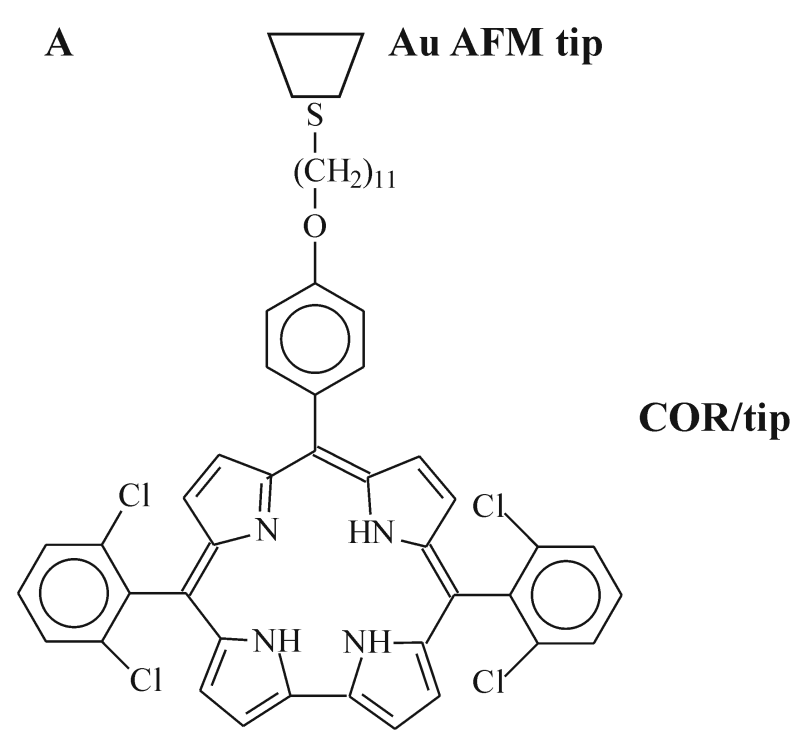

B

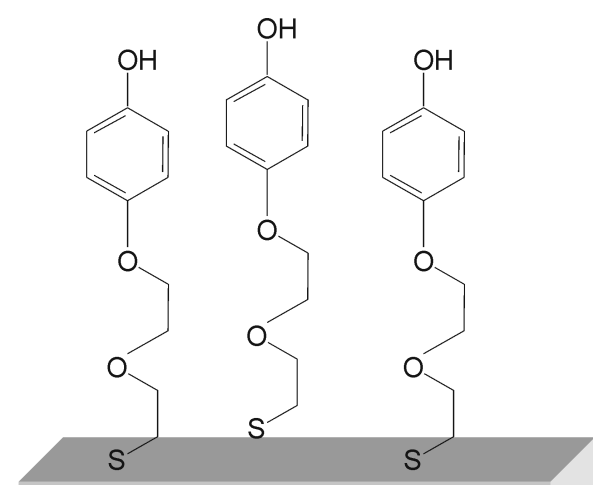

$\mathrm{Ph} /$ substrate
C

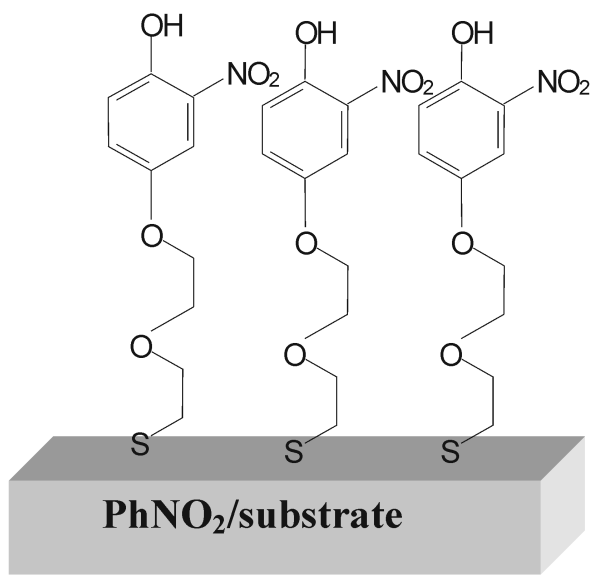

\section{Gold substrates}




\section{Scheme 2.}

Structure of the complex between corrole with an ortho - nitrophenol derivative optimized by AM1 geometry (CaChe Worksysem Pro Version 7.5.0.85).

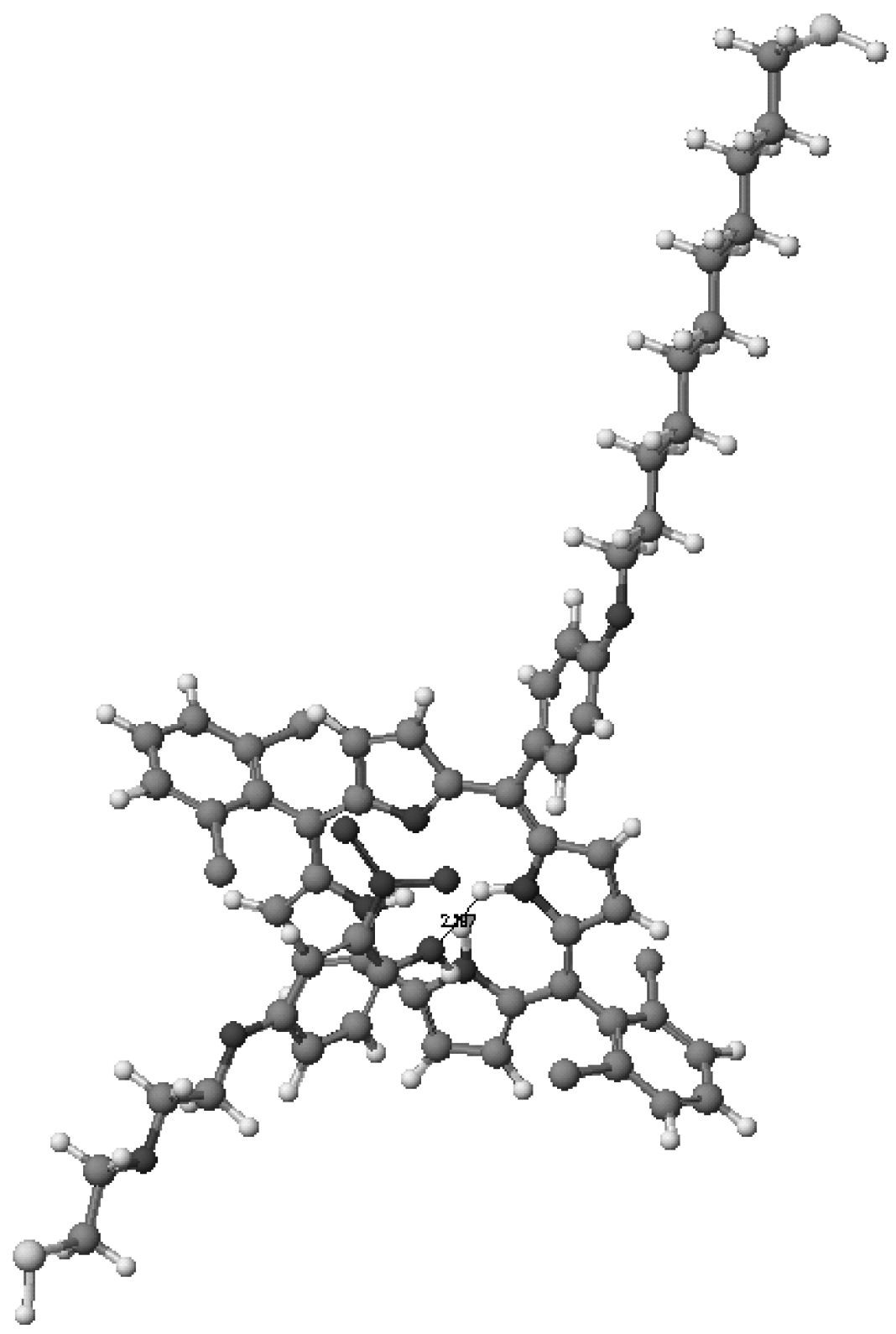




\section{Figure 1.}

Typical force curve (line "B" - approaching, b line "A" - retracting) observed for $\mathrm{PhNO}_{2}$-substrates using COR/tip made in water.

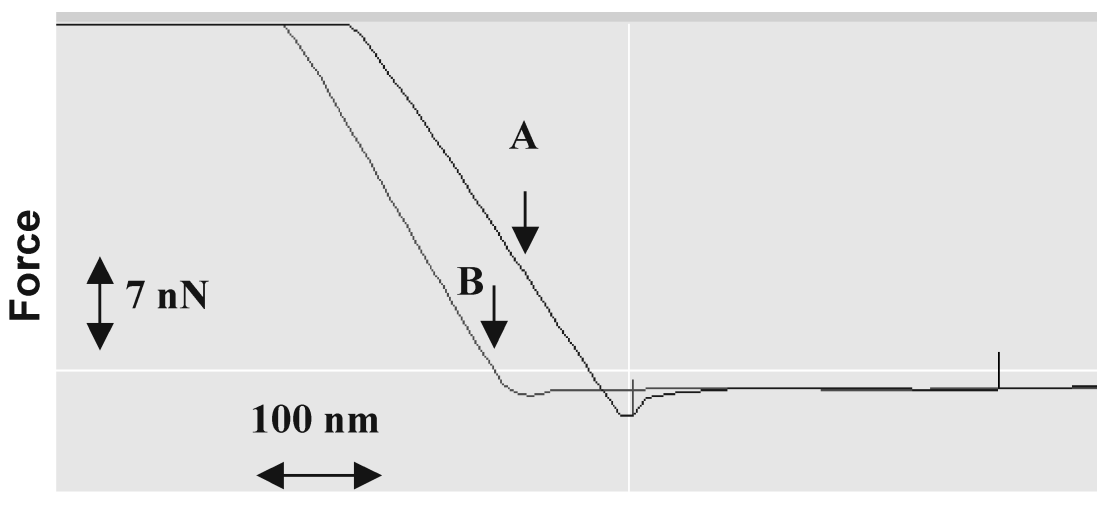

Displacement 


\section{Figure 2.}

(A) Histogram of adhesion forces obtained from the repetitive force measurements between single $\mathbf{C O R} /$ tip and $\mathbf{P h} /$ substrate in water. (B) A plot of mean vs. variance of adhesion force measured for $\mathbf{P h} /$ substrates using five separate COR/tips in water.

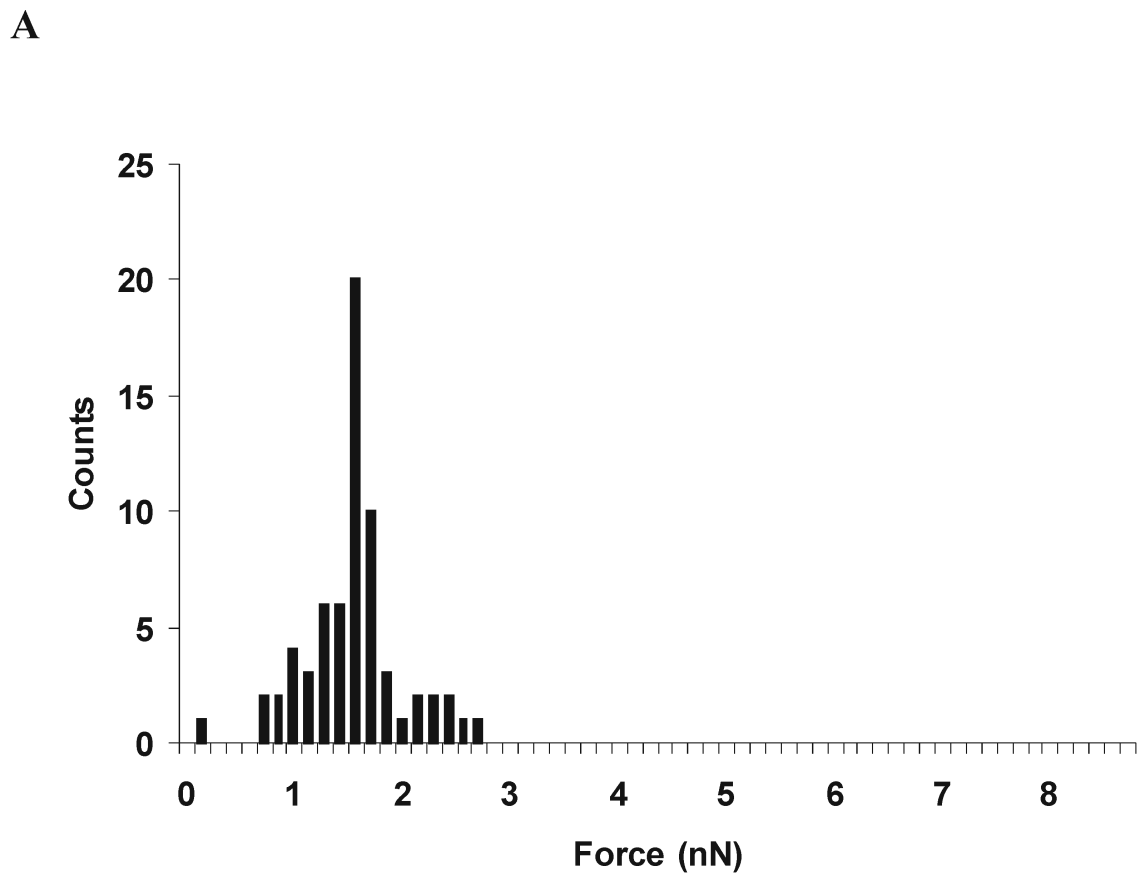

B

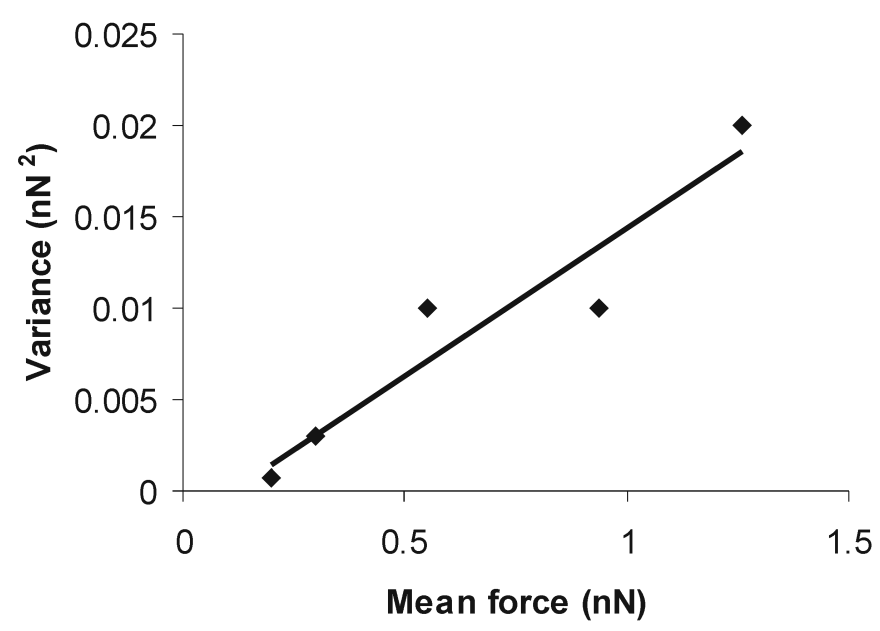




\section{Figure 3.}

(A) Histogram of adhesion forces obtained from the repetitive force measurements between single $\mathbf{C O R} /$ tip and a $\mathbf{P h N O}$ /substrate in water. (B) A plot of mean vs. variance of adhesion force measured for $\mathbf{P h N O}_{2}$ /substrates using three separate COR/tips in water.

A

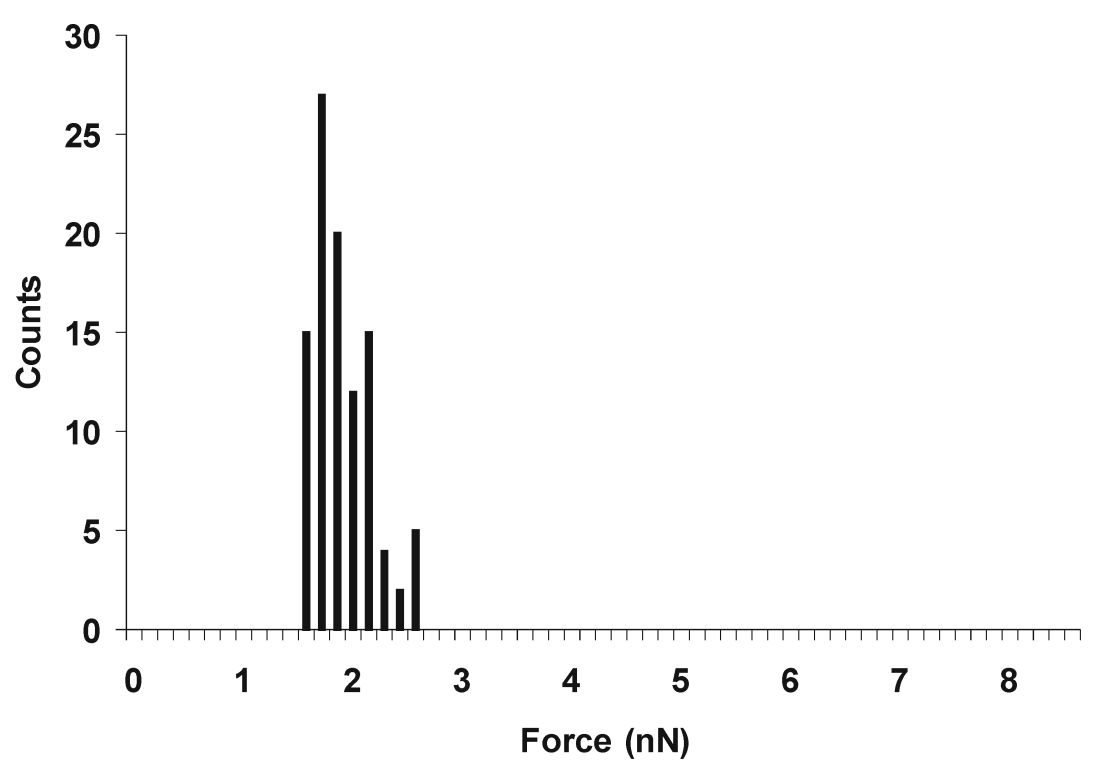

B

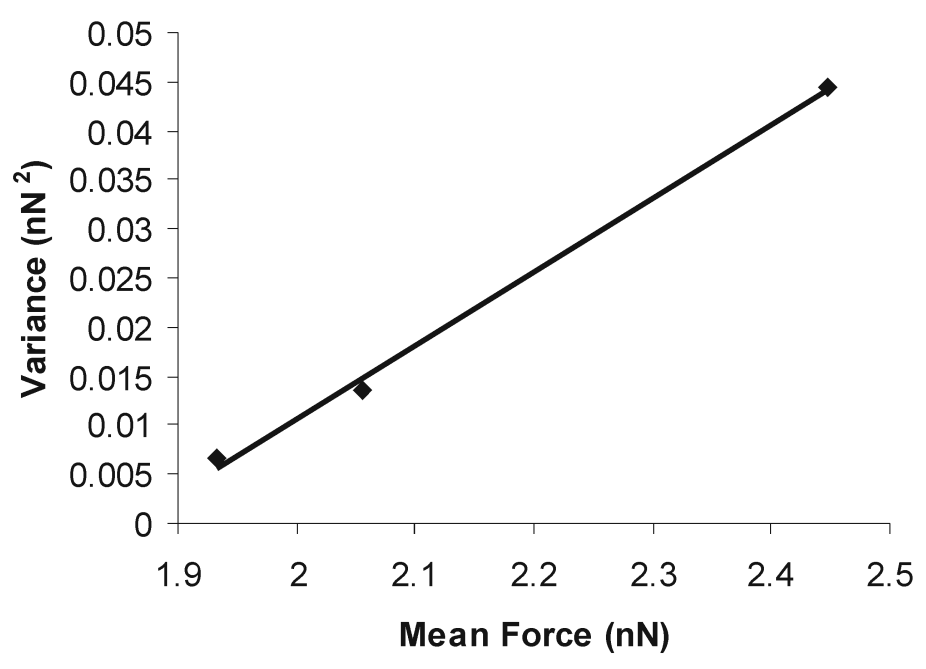




\section{Figure 4.}

Histograms of adhesion forces $(n=300)$ obtained from the repetitive force measurements between a bare gold AFM tip and a $\mathbf{P h} /$ substrate $(\mathbf{A})$ and a $\mathbf{P h N O} \mathbf{2}_{2}$ substrate (B) in water.

A

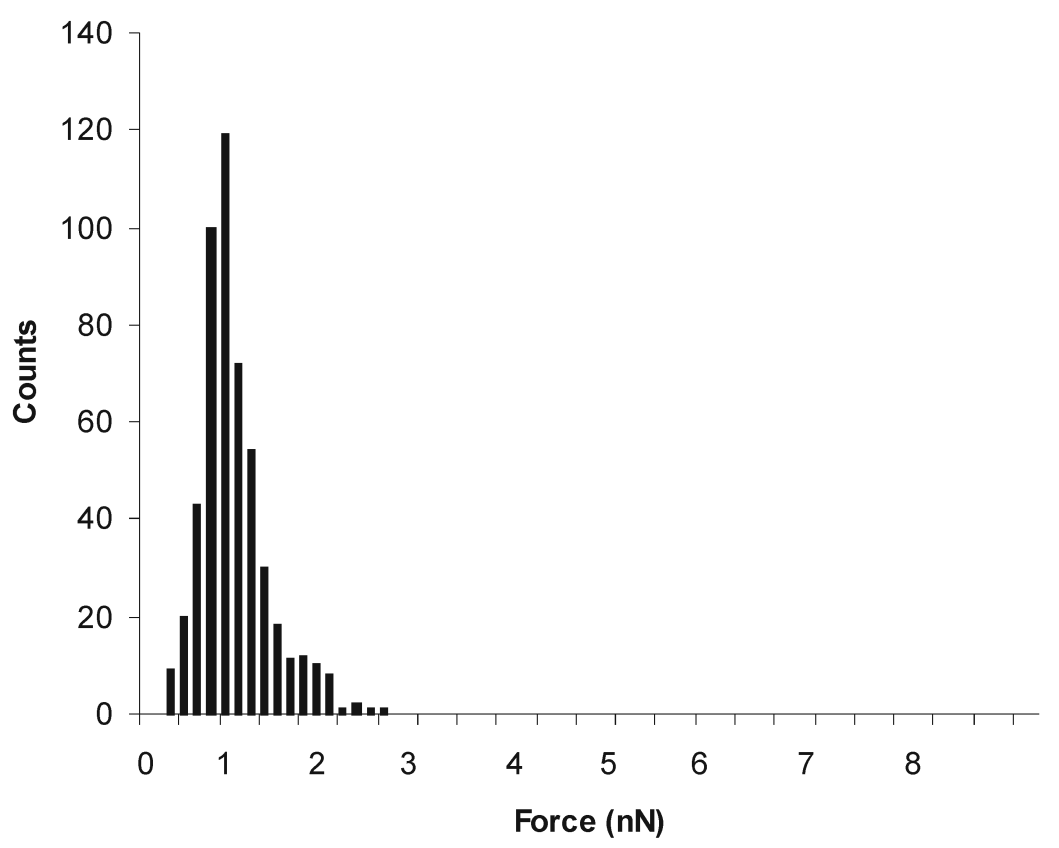

B

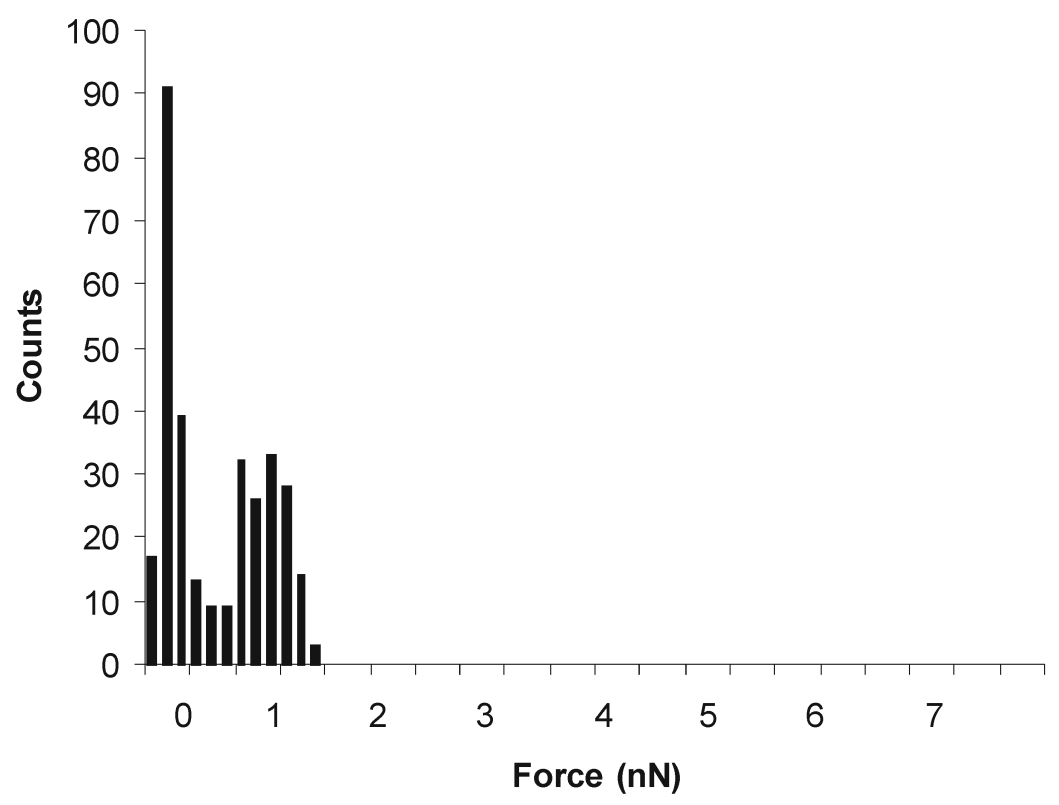




\section{Figure 5.}

(A) Histogram of adhesion forces obtained from the repetitive force measurements between single $\mathbf{C O R} /$ tip and a $\mathbf{P h} /$ substrate in $0.1 \mathrm{M} \mathrm{K}_{2} \mathrm{SO}_{4}(\mathrm{pH}$ 6.0). (B) A plot of mean $v$ s. variance of adhesion force measured for $\mathbf{P h} /$ substrates using three separate $\mathrm{COR} /$ tips in $0.1 \mathrm{M} \mathrm{K}_{2} \mathrm{SO}_{4}(\mathrm{pH} \mathrm{6.0)}$.

A

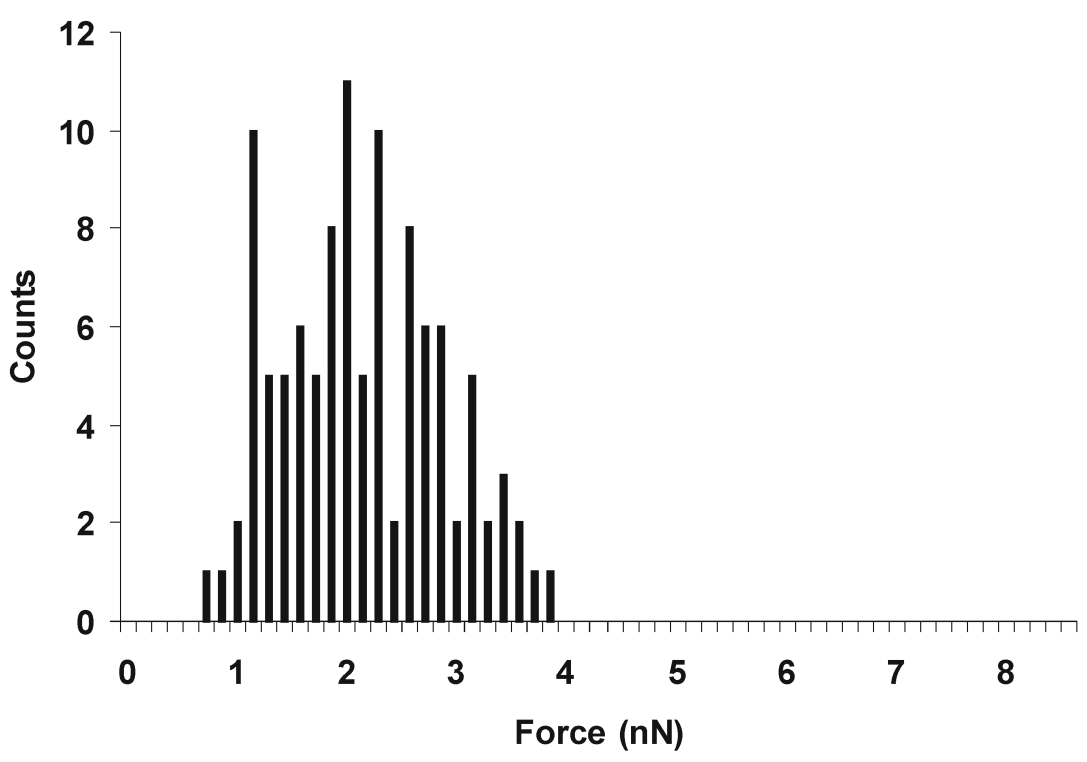

B

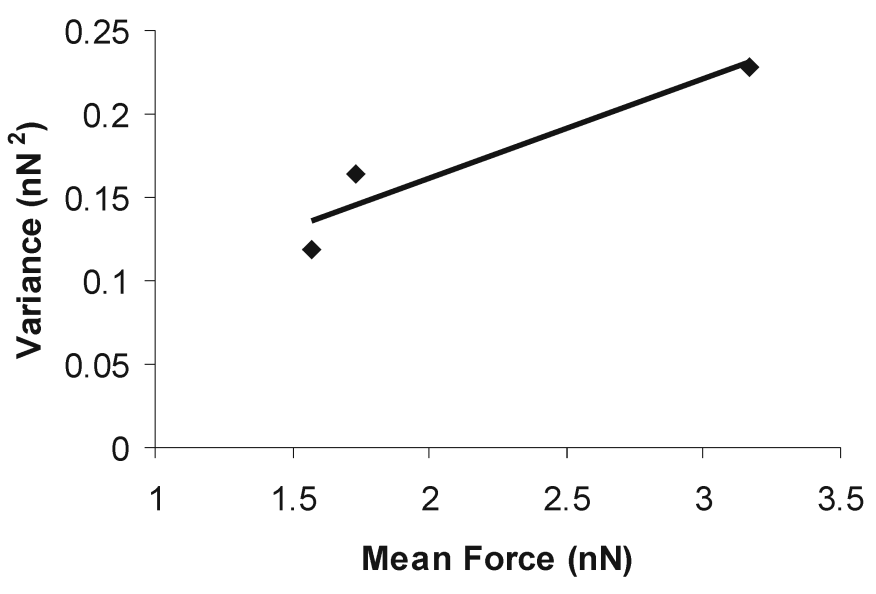




\section{Figure 6.}

(A) Histogram of adhesion forces obtained from the repetitive force measurements between single $\mathbf{C O R}$ /tip and the $\mathbf{P h N O}_{2}$ /substrate in $0.1 \mathrm{M} \mathrm{K}_{2} \mathrm{SO}_{4}(\mathrm{pH} 6.0)$. (B) A plot of mean vs. variance of adhesion force measured for $\mathbf{P h N O}_{2}$ /substrates using four separate COR/tips in $0.1 \mathrm{M} \mathrm{K}_{2} \mathrm{SO}_{4}(\mathrm{pH}$ $6.0)$.

A

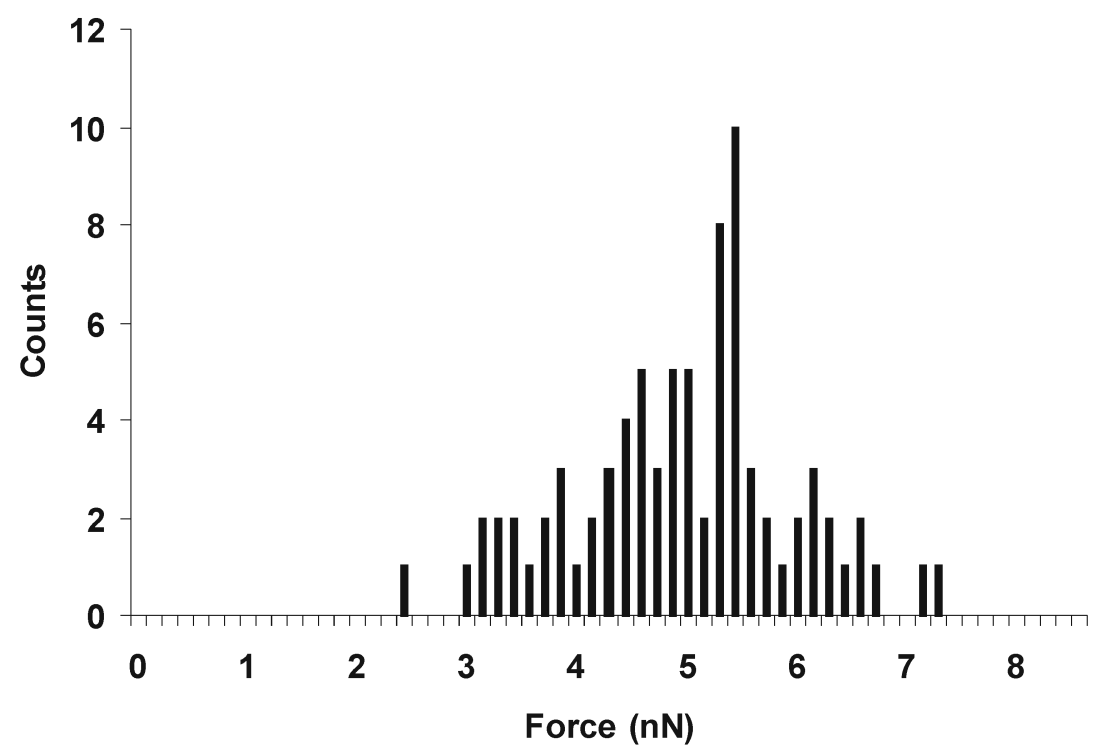

B

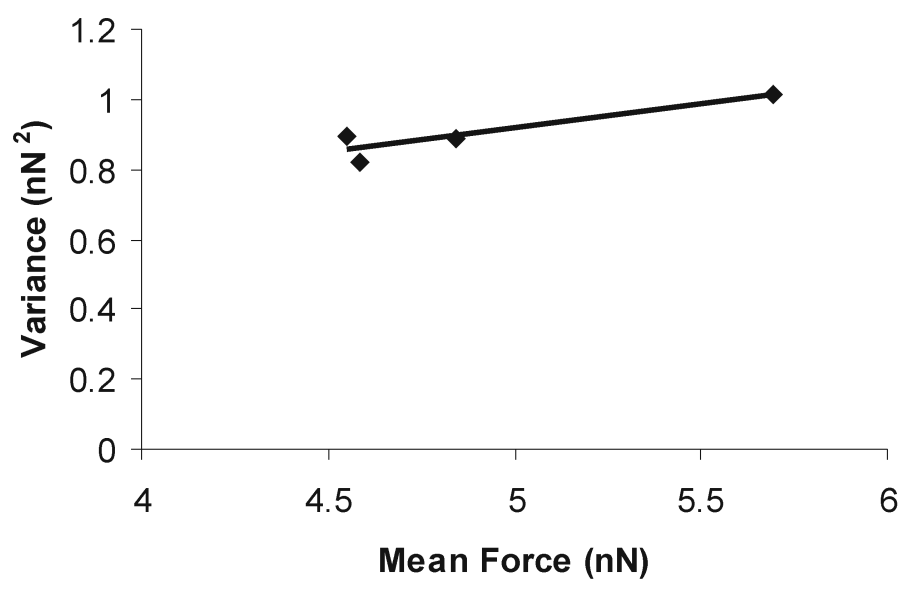




\section{Figure 7.}

Typical force curve (line "B" -approaching, b line "A" - retracting) observed for $\mathrm{PhNO}_{2}$-substrates using COR/tip made in $0.1 \mathrm{M} \mathrm{K}_{2} \mathrm{SO}_{4}$ at $\mathrm{pH} 10.0$.

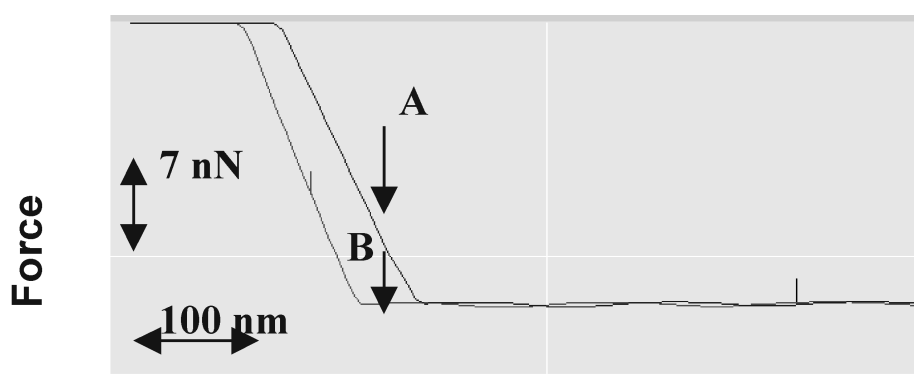

Displacement 


\section{Table 1.}

Adhesion forces measured with unmodified and corrole-modified tips and gold substrates modified with $\mathrm{Ph}$ or $\mathrm{PhNO}_{2}$ in different aqueous solutions.

\begin{tabular}{|c|c|c|}
\hline & $\mathrm{Ph} /$ substrate & $\mathrm{PhNO}_{2} /$ substrate \\
\hline unmodified tip, water & $1.0 \pm 0.2 \mathrm{nN}$ & $0.7 \pm 0.2 \mathrm{nN}$ \\
\hline COR/tip, water & $1.7 \pm 0.3 \mathrm{nN}$ & $2.1 \pm 0.5 \mathrm{nN}$ \\
\hline $\begin{array}{c}\text { COR/tip, } \\
0.1 \mathrm{M} \mathrm{K}_{2} \mathrm{SO}_{4,} \mathrm{pH} 6.0\end{array}$ & $2.2 \pm 0.6 \mathrm{nN}$ & $5.0 \pm 0.8 \mathrm{nN}$ \\
\hline $\mathrm{COR}_{\mathrm{C} / \mathrm{tip},}$ & $0 \mathrm{nN}$ & $0 \mathrm{nN}$ \\
\hline $0.1 \mathrm{M} \mathrm{K}_{2} \mathrm{SO}_{4}, \mathrm{pH} 10.0$ & & \\
\hline
\end{tabular}




\section{Table 2.}

Single bond forces measured with corrole-modified tips and $\mathrm{Ph}$ and $\mathrm{PhNO}_{2}$ compounds immobilized on gold substrates in different aqueous solutions.

\begin{tabular}{|c|c|c|}
\hline & $\mathrm{Ph} /$ substrate & $\mathrm{PhNO}_{2} /$ substrate \\
\hline COR/tip, water & $16.1 \pm 3.0 \mathrm{pN}$ & $75.1 \pm 11 \mathrm{pN}$ \\
\hline $\begin{array}{c}\mathrm{COR} / \mathrm{tip}, \\
0.1 \mathrm{M} \mathrm{K}_{2} \mathrm{SO}_{4,} \mathrm{pH} 6.0\end{array}$ & $59.3 \pm 10.0 \mathrm{pN}$ & $140.5 \pm 33.0 \mathrm{pN}$ \\
\hline $\mathrm{COR}_{\mathrm{C} / \mathrm{tip},}$ & $0 \mathrm{pN}$ & $0 \mathrm{pN}$ \\
\hline $0.1 \mathrm{M} \mathrm{K}_{2} \mathrm{SO}_{4}, \mathrm{pH} 10.0$ & & \\
\hline
\end{tabular}

